\title{
Editorial
}

\section{The brand is dead: Long live the brand}

Since Marlboro Friday, it has been fashionable to argue that brands are dead. The rise of retailer brands (Private Label) and of discount chains, such as the German Aldi group, are given as confirmation. The Economist has asserted that traditional consumer marketing departments are being abolished and that the brand manager is dead. 1

In fact, the death of brands is a proposition that is superficially attractive but has no substance. Quality consumer and customer marketing is more important than ever before, and remains a critical source of competitive advantage. The evolution of consumer marketing in the last 30 years demonstrates this.

(1) The 1960s-70s - Smoke and mirrors. Prior to the 1970 s, brand marketing was more cavalier. It was enough to persuade consumers that a brand had the right values, even if the performance left a little to be desired. Advertising controls were looser, and consumers were less demanding - moreover, they were less well informed. Price was dictated by apparent value. Perception underpinned many strong market shares.

(2) The 1980s - The technology era. Shifts in market share revealed to many large companies that their approach to brand marketing was no longer adequate. Consumers could not be easily persuaded, for instance, that their clothes would be whiter - the product had to deliver as well. Worse still, under-performers were rejected - incredibly, consumers were found to be intelligent!

Consequently, innovations such as shower liquids and microwave products began to displace long-standing market leaders. In many cases, functional performance differentiated the brand. As traditional products lost ground, there was a rush for new product pluses that would give a competitive advantage.

It was assumed the consumers were sure to appreciate a better product, so it became less important to focus so closely on her own desires. The result was duller marketing skills, while Marketing departments lost status, to say nothing of glamour. New Coke is a good example of a product which consumers did not buy - they just didn't want the original flavour changed.

(3) The 1990s - Real value for intelligent consumers. Modern consumers are discerning and sophisticated. They want products that deliver, and brands with which they can identify. They want good value for money.

Technology, hence product performance, is still as important as it was a few years ago. However, there are so many alternatives available that functional benefits alone are not enough. Technology is necessary but not sufficient. Consumers have emotional and psychological motivations and successful brands must satisfy these too. Wall's Magnum is the fastest growing ice cream in the world. It is a high quality product in tune with modern consumer aspirations. It is more expensive than other ice cream sticks, but its success proves it must be good value.

Private Label brands strive to satisfy these desires too. Indeed, retail chains have domi- 
nated advertising expenditure in recent years. This reveals Private Label brands to be exactly what their name suggests - brands. The values they offer are those of the retailers itself. Advertising for Sainsbury, Tesco or Boots is as much promotion of their brands as of the stores themselves. The rules of war are clear. Give the consumer what she wants where she shops, and she may buy your brand. Therefore, the rise of Private Label is neither inexorable nor inevitable.

On the other hand, weak brands, lack of innovation, or poor value will cause brands to decline.

IBM came face to face with over-dependence on a product that did not evolve to meet changing demands and which lost sight of its consumers. Compaq, which has consistently offered high quality good value PC's, is now market leader in the United States.

Marlboro lost market share as it became expensive compared to lower quality cigarettes. It no longer justified its price premium for many loyal consumers. On the other hand, Lexus cars have made enormous inroads in the premium car market by including more features and reliability at no extra cost. The old maxim: 'If you have to ask you can't afford it' is no longer true whatever their prestige, all brands must offer good value.

It would be perverse, to say the least, to reduce the emphasis on brand marketing in view of the above. In fact, recent trends point to an increased focus on customers, and a growing importance of brands. The pace of change, especially of innovation, has never been faster. A deep knowledge of the customer is necessary to stay ahead. There will not be space for as many players in fu- ture; only those brands based on a real knowledge of the consumer will grow.

The move to cross-discipline teams, commented on by The Economist, reflects the need for all management to know the consumer better. Innovation is the name of the game. Everybody in the Company must pursue the same goals. Speed is the only way to secure a few months' advantage over competitors. But however rapidly it is developed, brand mix must still be optimised at the lowest cost. Relevant technology is a pre-requisite for success; unnecessary functions or frills do not enhance brand appeal but will add cost. Consumers will not pay for them, so they must be eliminated.

Consumer choice depends as much on function, and brand values as ever before. Brands which remain contemporary through innovation will grow, provided they offer good value for money. Businesses must change continuously to meet this challenge. The evolution of management and marketing will continue and companies will restructure time and again. The most critical success factor for consumer goods companies, namely the satisfaction of consumer needs and wants, is as important as ever.

Consumer marketing is here to stay. Brands are alive and kicking. But companies that relax, or brands which become complacent, will suffer. That was the lesson of Marlboro Friday.

\section{Reference}

(1) 'Death of the Brand Manager', (1994) The Economist, 9th April.

\section{Ralph Kugler Editorial Board}

